\title{
SOCIALIZATION OF GOOD AND TRUE TRAFFICKING OF MADRASAH IBTIDAIYAH DAARUL 'ULUM SOUTH JAKARTA
}

\author{
Acep Hidayat, Muhammad Isradi, and Soh Aly \\ Universitas Mercu Buana Jakarta, Indonesia \\ Union of The Youth Federation of Cambodia, Cambodia.
}

\begin{abstract}
ABSTRAC
The accident rate in Indonesia tends to be quite high when compared to other countries in Asean. Traffic accidents are one of the causes of death in the world (8th rank), and the main cause of death of young people aged 15 to 29 years. Accidents can be prevented by various technical countermeasures, this needs to be done so that unnecessary accident costs can be reduced. Against this background, it is necessary to conduct socialization early on about good and correct traffic procedures especially for young children at the elementary school level, so it is expected that our children already have the provision of information and techniques about traffic in our country.
\end{abstract}

Keywords: Socialization, Good Traffic

\section{BACKGROUND}

The World Health Organization under the auspices of the United Nations (WHO) recently released The Global Report on Road Safety, which shows the number of traffic accidents that occur throughout the year in 180 countries. It is not surprising to see the name Indonesia on this list considering the number of motorists in Indonesia who are often found committing traffic violations. In fact Indonesia is the third country in Asia under China and India with a total of 38,279 total deaths due to traffic accidents in 2015. Indonesia is ranked third in the data but seen from the statistical percentage of the population, Indonesia ranks first with a mortality rate of 0.015 percent of the population under China with a percentage of 0.018 percent and India 0.017 percent. (Source: Analisadaily \& WHO). Even though the total number of accidents and injuries decreased, there is one thing that is of concern, namely the death toll remains high. In eleven months of 2014 as many as 26,623 people lost their lives on the streets, a tendency to increase compared to 2013 which was 26,416 . The death toll is more common among motorcycle users. The causes are said to vary, for example violating traffic, disobeying signs, and not being able to drive properly.

WHO also released data that traffic regulations in Indonesia do not strictly regulate the practice of regulating speed in driving, driving while intoxicated, wearing helmets, using seat belts and child safety while driving. Besides Indonesia, the United States, Pakistan, Nigeria and Bangladesh are also included in the list of countries with the highest mortality rates from traffic accidents in the world.

Putranto (2013) found a significant relationship between age and education level on harmful behavior in the use of motorbikes. The younger the age and the lower the level of education of the motorcycle driver, the higher the tendency to behave in a dangerous manner in the use of motorbikes.

Miro (2012) intersection is a vertex of three or more ends of a road segment that meets or one end of a road segment that meets a half-way segment (intersection of three) in a plot. At this intersection there is a gathering of traffic flows from various directions of the crossing (road sections) or places where some traffic flows. Under these conditions, traffic flow conflicts will occur (all road users want to go ahead to get to another intersection) so that this conflict does not occur or at least is minimized, management needs to be done through the following (technical) methods:

- Priority, prioritizing or giving the first opportunity for traffic flow on the main road by installing a "stop" sign at the end of the minor road section.

- Turn, giving each traffic flow a turn manually by the traffic police officer or the transportation department

- Smart traffic lights, further intersection efficiency can be done by the use of smart traffic lights that are controlled automatically at signal intersections.

Even though traffic lights are installed on the basis of legal guarantees, they must still meet safety, travel time, eligibility requirements and so on. Some of the advantages are positive guidance / directions for vehicle drivers and pedestrians, thereby reducing the wrong decision making by the driver, allocating priority rights and can reduce the frequency of accidents (Khisty \& Lall, 2005). 
To foster traffic discipline to the community, it should be done from an early age by introducing the meaning of existing traffic signs commonly found on the highway to children. Given the times have changed, lately more and more vehicles have passed on the streets. Many people use their vehicles as they wish, without thinking about the conditions and environment and the existing traffic regulations.

\section{PURPOSE}

The impact and benefits of community service that have been carried out can be grouped into two, namely:

1. Short-term,

Students' knowledge about good traffic increases

2. Long-term

It is expected that students can obey the rules in terms of traffic, and can reduce the level of violations in traffic

\section{METHOD APPLICATION}

The main activity is to provide socialization and improve knowledge to students about good and right traffic. The method used is to give an explanation to grade 4 students by presenting several teaching aids such as:

$\neg$ Pictures about traffic signs, pictures of types and types of intersections,

$\neg$ Video of the procedure for crossing a good road,

$\neg$ Video hierarchy of vehicles that will cross the intersection,

$\neg$ Videos about the meaning of traffic lights at signal intersections, etc.

In its implementation, this activity is carried out in several stages, namely:

- Providing socialization to students about traffic signs by displaying pictures or baners containing traffic lights, traffic signs, zebra crossings, types and types of intersections.

- Provide visual socialization to students by watching a comparative video about the procedures for crossing good and bad roads, crossing by crossing zebra crossings or crossing bridges.

Dissemination to students by displaying videos about the vehicle hierarchy that will cross the intersection and understanding of traffic lights signal

\section{RESULT}

From the socialization activities, students are collected in the classroom then we present material about the dissemination of knowledge about good and right traffic. Displayed pictures and video shows about good and right traffic location of community service. At first the students had very poor thought patterns and understanding of traffic information both on how to cross through zebra crossing, on the understanding of traffic lights, road markings and signs of traffic signs. Also an understanding of the dangers of using motor vehicles for the age of children and what consequences will arise from the use of motor vehicles in the age of children. Dalam kegiatan ini juga diberikan pembahasan dan evaluasi dari hasil sosialisasi, dimana diakhir kegiatan siswa diberikan pertanyaan tentang materi yang telah disampaikan sebagai bahan evaluasi bagi Tim pelaksana.
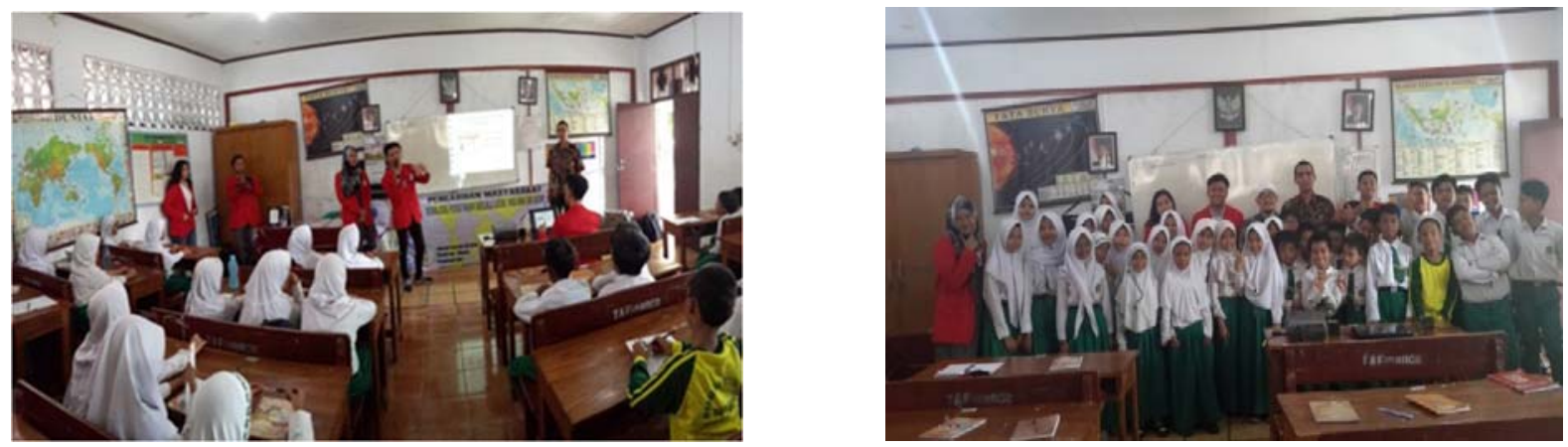


\section{CONCLUSION}

This socialization activity provides and improves students' understanding of good and correct traffic for MI Daarul Ulum Pancoran Students, Jakarta. Any benefits and impacts that can occur by behaving obediently will be good and right traffic. Conveyed the dangers and sanctions due to the use of motor vehicles in the age of children.

The activeness of students in this activity in the form of discussion and question and answer is expected to increase students' insight and knowledge of the importance of good traffic and is expected to be applied in daily activities

\section{REFERENSI}

1. Khisty, C. Jotin \& B. Kent Lall. (2005). "Fundamentals of Transportation Engineering". Erlangga Jakarta

2. http://dishub.jabarprov.go.id/-13 November, 2016

3. http://ntmcpolri.info/korlantas-polri-13 November, 2016

4. http://ragam.analisadaily.com/read/who-29 May, 2016

5. Miro, Fidel. (2012), "Introduction to Transportation Systems". Erlangga, Jakarta

6. Putranto, L.S, (2013), Traffic Engineering, Index, Jakarta 